\title{
Relatos fantasmas: os filmes históricos cinemanovistas e a política cultural da ditadura civil-militar nos anos 1970
}

Carlos Eduardo Pinto de Pinto' 


\section{Resumo}

A proposta do artigo é refletir acerca das relações entre memória e história por meio do embate entre o Cinema Novo e a ditadura civil-militar nos anos 1970, período que corresponde à sistematização da política cultural dos governos militares. Entre as estratégias mobilizadas por esta, estava o incentivo à construção de uma cultura histórica pautada por leituras ufanistas do passado nacional, em que ganhava destaque a produção de filmes históricos. Como forma de aproximação do tema, aqui são abordadas duas obras: Os herdeiros (Cacá Diegues, 1969) e Coronel Delmiro Gouveia (Geraldo Sarno, 1977). Mesmo realizados em momentos distintos de tal política cultural, os filmes elaboram estratégias de resistência semelhantes. Em ambos, recorrese à memória para uma contraposição à história ufanista exortada pelos governos, ela mesma resultado de reelaborações da memória. Como é típico da cultura histórica que abarca qualquer discurso sobre o passado, mesmo os produzidos fora do âmbito acadêmico -, é possível perceber, nos dois lados da disputa, a presença fantasmática da memória a assombrar a história.

\section{Palavras-chave}

Memória, filmes históricos, Cinema Novo, ditadura civil-militar. 


\section{Abstract}

The article aims to analyze the relationship between memory and history on the struggle of Cinema Novo facing the civil-military dictatorship during the 70's in Brazil, period in which the cultural policy of the military government was settled. In amidst the strategies of such policy was the support to a historical culture that established a nationalistic representation of the past, in which the historic movie production was propelled. Regarding our approach, two movies are to be considered: Cacá Diegues' Os herdeiros (1969) and Geraldo Sarno's Coronel Delmiro Gouveia (1977). Even though they were produced on different time periods under such policy, these films convey similar resistance strategies. It is possible to notice on both of them the use of memory to fight against the nationalist history elicited by the government, that, on its turn, was also established by memory restructuring process. Also common on historical culture that comprises different versions of the past, including those created outside academy -, it is possible to realize, on both sides of such struggle, the phantasmagoric presence of memory haunting history.

\section{Keywords}

Memory, historic movies, cinema novo, civil-military dictatorship. 


\section{O Cinema Novo e o desejo de história}

O Cinema Novo foi um movimento de vanguarda que marcou indelevelmente a produção cultural brasileira entre 1960 e 1980 . Além da realização de dezenas de filmes, entre documentários e ficções, também contribuiu para diversos debates teóricos, tanto de cunho estritamente cinematográfico, quanto os referentes a áreas como política, sociologia, história e antropologia - sempre defendendo ideologias de esquerda. Por conta disso, é comparado aos movimentos modernistas, em que "a arte se relacionava com o político não só por seu pertencimento à polis, mas também por sua consideração como motor do social (...)" (ALTUNA, 2007: 13. Tradução nossa)². Devido a esse teor politizado e esquerdista, a interlocução (e, mais frequentemente, o embate) com a ditadura civil-militar (1964-1985), ganhou diversos níveis de intensidade até a dissolução do movimento, no início dos anos 1980.

O momento analisado aqui diz respeito ao período pós-1968, quando começou a se delinear, por parte da ditadura, uma política cultural. Esta viria sistematizar posicionamentos manifestados, até então, em exortações e elogios a obras paradigmáticas e na censura às consideradas subversivas. Vale notar o papel central que a preservação da história (não raro confundida com a memória) ocupou no estabelecimento dessas diretrizes. Nesse âmbito, ganharam destaque os filmes históricos, considerados interessantes por conta de seu alto poder de mobilização - o que não guarda, necessariamente, correspondência com as pesquisas historiográficas. Como indica Serge Berstein (1962: 69): “... na ordem da cultura política, é a lenda que é a realidade, pois é ela que é mobilizadora e determina a ação política concreta, à luz da representação que ela propõe”.

Ambos os filmes analisados aqui - Os herdeiros (Cacá Diegues, 1969) e Coronel Delmiro Gouveia (Geraldo Sarno, 1977) - se aproximam desse gênero cinematográfico, embora nos dois casos se recorra a algum nível de subversão de suas regras clássicas. Vale informar que o filme histórico se mostrava interessante aos cinemanovistas também por se mostrar útil à realização de seu desejo

2. "el arte se relacionaba con lo político, no solo por su pertenencia a la polis, sino por su consideración como motor de lo social (...)". 
ano 2 número 3

Dossiê

de conhecer e explicar a brasilidade através da arte. Marcelo Ridenti (2000) denominou de romantismo marxista a postura desses artistas que "pretendiam revolucionar a sociedade em direção ao futuro e buscavam para tanto o encontro com as raízes do passado, em meio a um acelerado processo de modernização e urbanização da sociedade" (RIDENTI, 2000: 95). De diversas maneiras, tanto na elaboração estética quanto nos discursos teóricos extrafílmicos, os cineastas pertencentes ao Cinema Novo manifestavam um desejo de história, uma vontade de explicar o mundo através da historicidade de suas variáveis.

Logo, o filme histórico era um gênero em que os interesses da ditadura e dos cinemanovistas se encontravam. Contudo, tanto para os governos quanto para os cineastas, se estabelecia uma indistinção entre memória e história no momento de se eleger os temas a serem representados em tais obras. Enquanto para os governos a mobilização da memória servia a moldar uma história mais palatável e de acordo com suas perspectivas sobre o passado nacional, para os cineastas essa mesma promiscuidade entre as duas áreas ganhava contornos contestatórios: a memória serviria a corrigir a história. Afinal, a memória é sempre uma questão de poder, em qualquer nível em que se apresente a possibilidade de seu exercício (LE GOFF, 1986).

Para Fernão Ramos (1987), o interesse pelo filme histórico teria sido mais intenso no que ele denomina "terceira fase" do Cinema Novo, quando, como uma reação à assinatura do AI-5, o movimento passou a apresentar produções de "fortes tons alegóricos com a preocupação de representar o Brasil e sua história" (RAMOS, 1987: 348). Tal transformação é explicada pela necessidade de repensar a realidade brasileira em outros termos que não o da revolução socialista, já que, impedidos pela censura de fazer filmes em que criticassem a realidade e propusessem mudanças estruturais - elementos típicos de suas fases iniciais - os cineastas passaram para uma via reflexiva, onde buscavam a essência do país através de alegorias ou da história.

Concordo com o autor em parte, pois acredito no impacto do Golpe de 1964 e, principalmente, do AI-5 sobre a produção desse período. Contudo, como apontei 
acima, percebo a existência de um desejo de história que não se manifesta somente após os golpes. Ele é anterior e tem status de elemento fundador da geração (PINTO, 2005; 2013). O período pós-1968 apenas fez com que ele se tornasse mais explícito e mais angustiado.

\section{A política nacional de cultura e os filmes históricos}

A relação dos cineastas com a ditadura ultrapassou o plano dos embates simbólicos quando os governos ditatoriais passaram a delinear uma política cultural mais propositiva a partir de 1975. No horizonte dessas mudanças, estava a atuação da Embrafilme, empresa estatal de cinema criada em 1969, como complemento ao Instituo Nacional de Cinema (INC), fundado em 1966. A empresa auxiliar aumentaria seu poder paulatinamente até que, no meio da década de 1970, viria a substituir o INC (AMANCIO, 2000). Percebe-se um aumento da burocratização da área, o que leva a um controle maior da produção. Tal estratégia se mostra mais eficiente do que as exortações e a censura, características dos primeiros anos da ditadura. Nessa nova conformação, os cinemanovistas precisariam dialogar para continuar trabalhando, embora diversos meios de combate ainda fossem viáveis. Afinal, diálogo não é, necessariamente, sinônimo de cooptação.

A política cultural do regime civil-militar, de cunho altamente nacionalista, apresentava forte interesse em preservar/erigir uma memória nacional que passava, indubitavelmente, pela mobilização de uma cultura histórica. Segundo Angela de Castro Gomes (2007), o conceito se refere à relação que uma sociedade mantém com seu passado, pautada não apenas pela historiografia, mas também pela cultura política. Dessa forma, com a proposta de moldar uma cultura histórica, os ditadores dispensavam atenção especial ao ensino de história, à criação e dinamização de museus, bem como à conservação e revitalização de cidades históricas, sempre a partir de uma perspectiva em que o passado assumia contornos grandiosos, dignos de respeito.

O mesmo viés pode ser encontrado nas exortações discursivas e nos concursos estatais de produção de roteiros de filmes históricos, em que o passado deveria ser - mais que representado - reverenciado. É o caso de um discurso de Jarbas 
ano 2 número 3

Dossiê

Passarinho, então ministro da Educação e Cultura, que, em 1971, incentivava a produção de filmes sobre o heroísmo nacional. Algumas instituições e personagens históricos citados eram: Força Expedicionária Brasileira, Correio Aéreo Nacional, Borba Gato, Anhanguera, Paes Leme, Oswaldo Cruz, Santos Dumont, Delmiro Gouveia, duque de Caxias e marechal Rondon. Esse último chama atenção, pois, segundo o ministro, "permitiria que se traçasse um paralelo histórico com outras nações que, ao contrário do Brasil, dizimaram seus índios durante a campanha de conquista" (FILME CULTURA, 1971). Tal afirmação, referente a um aspecto da história brasileira de caráter reconhecidamente violento, demonstra o grau de maleabilidade que a memória (tratada como história) oferecia.

Coadunando-se com essa postura, a forma privilegiada pelos agentes responsáveis por selecionar os filmes históricos dos concursos ou das produções da Embrafilme era o épico clássico - filmes históricos que têm, entre suas características, a grandiosidade e o tom espetacular, aspectos priorizados frente à veracidade dos eventos encenados (VADICO, 2012). Apesar dos esforços governamentais, no período houve apenas três representantes desse estilo Independência ou morte (Carlos Coimbra, 1972), O mártir da independência (Geraldo Vietri, 1977) e O caçador de esmeraldas (Oswaldo de Oliveira, 1979). Não obstante o pequeno número de produções, vale informar que a primeira da lista, Independência ou morte, foi acatada pela ditadura civil-militar e se constituiu em um dos maiores sucessos de bilheteria da época (PINTO, 2005).

Por outro lado, os cinemanovistas foram os responsáveis pela grande maioria dos filmes históricos da década, muito embora aqui seja necessário assinalar que, apesar de se manter a referência ao gênero, a aproximação se dava privilegiadamente pelo viés da alegoria (RAMOS, 2002). Este é o caso de Os herdeiros, analisado aqui, e também de Os deuses e os mortos (Ruy Guerra, 1970), Pindorama (Arnaldo Jabor, 1971), Como era gostoso meu francês (Nelson Pereira dos Santos, 1971) e Os inconfidentes (Joaquim Pedro de Andrade, 1972). Em alguns casos, se recorreu à comédia, como em Xica da Silva (Cacá Diegues, 1976) e, em outros, à história oral, como em Coronel Delmiro Gouveia, também foco de análise aqui. 
Qualquer que seja o recurso narrativo, no entanto, vale notar que tais filmes passam ao largo do estilo épico exortado pelos governos. São obras que estabelecem um distanciamento em relação à história, rompendo a tentativa de fazer crer que, diante do espectador, se desenrolaria a história tal como aconteceu, o que é uma das características do épico. Afinal, a despeito de seu descompromisso com a noção de verdade histórica, o gênero mantém sua força de atração à custa da crença generalizada de que sejam legítimas portas de acesso ao passado. Para marcar a diferença em relação aos épicos clássicos, denomino as obras cinemanovistas como filmes históricos modernos - embora deva assinalar que a literatura sobre o tema apresente outras opções, como "filme histórico inovador" (ROSENSTONE, 2010: 36).

Mesmo não seguindo à risca as diretivas estatais, estes diretores e seus filmes acabam por se misturar à atmosfera da época, conseguindo facilidades nos canais de difusão, recebendo os ônus e os benefícios da opção políticocultural (RAMOS, 1987). Contudo, o caráter contestador desse tipo de produção se manteve, mesmo quando os cineastas tiveram suporte financeiro da Embrafilme. Os cineastas desvinculavam, em seus discursos, o plano econômico do cultural (RAMOS, 1983). Seria possível, segundo eles, fazer filmes produzidos pelo Estado sem se coadunar com as políticas culturais dos governos. Desse modo, o Estado era encarado como neutro e apenas o governo era de direita, uma equação facilitada pelo fato não haver ainda um movimento de controle total da produção.

Quanto aos filmes históricos, em 1975 foi criada uma comissão para escolher projetos, uma reedição do incentivo a se filmar os "momentos edificantes da História do Brasil" (FILME CULTURA, 1971), para citar as palavras do já referido discurso do ministro Jarbas Passarinho. Apenas dois projetos foram enviados, dos quais só Anchieta, José do Brasil (Paulo César Saraceni, 1978) foi realizado. Em 1977, a Embrafilme mudou de tática, se propondo a financiar os custos de investigação histórica de 18 roteiros que seriam filmados se aprovados pelo MEC. Obviamente, não seriam selecionados filmes com uma visão histórica indesejada pelo Estado. Contudo, o projeto não seguiu adiante, tendo se esgotado apenas na pesquisa. 
É importante perceber que essas propostas já estão coadunadas com uma política cultural mais elaborada, surgida a partir da implementação da Política Nacional de Cultura (PNC), cujo objetivo era formar um projeto homogêneo de política cultural no país. Tentava-se criar uma hegemonia ideológica e cultural tanto em setores populares (MOBRAL), como na classe média, com a criação ou dinamização de organismos como o Serviço Nacional de Teatro (SNT), o Instituto Nacional de Música (INM), a Fundação Nacional das Artes (Funarte) e na já citada Embrafilme, entre outras.

A concepção de cultura presente na PNC era de inspiração claramente antropológica, sendo encarada como "a plenitude da vida humana no seu meio" (RAMOS, 1983: 119). Estava fortemente baseada nas ideias dos intelectuais conservadores reunidos em torno do Conselho Federal de Cultura (CFC), criado já em 1965 e formado por profissionais egressos dos Institutos Históricos e Geográficos e das Academias de Letras. A base de sua concepção era a miscigenação cultural, como desenvolvida por Gilberto Freyre.

O convívio pacífico e a mistura das "três raças" fundadoras da nação teriam marcado o caráter brasileiro, explicando a suposta tolerância do país em relação a qualquer diferença cultural. A partir daí, a política da unidade nacional funcionava como um processo democrático, pois permitiria o convívio das diferenças regionais num todo harmônico. Segundo José Mário Ortiz Ramos, a "qualidade democracia passa dessa forma a constituir a essência da brasilidade, o que significa reconhecer a existência objetiva de uma 'verdadeira' cultura brasileira, espontânea, sincrética, plural” (RAMOS, 1983: 96). Outro aspecto do discurso do CFC diz respeito à tradição, entendida como patrimônio espiritual e material. O ser brasileiro (democrático e plural) e "o acervo legado pela história" (RAMOS, 1983: 96) formavam a tradição que deveria ser preservada. Daí a PNC considerar como seu objetivo primeiro "conservar o acervo constituído e manter viva a memória nacional, assegurando a perenidade da cultura brasileira" (RAMOS, 1983: 96). 


\section{Memória, herança incômoda}

Os herdeiros (1969) é o terceiro longa-metragem de Cacá Diegues, um dos cinemanovistas que mais dialogou com a história em seus filmes desde seu primeiro longa, Ganga Zumba (1963), passando pelo grande sucesso de bilheteria que foi Xica da Silva (1976). Ainda atuando como diretor hoje, mobiliza outros estilos narrativos para tratar de temas caros ao Cinema Novo - como o Carnaval, presente desde o seu primeiro curta profissional, Escola de samba Alegria de Viver, parte da obra coletiva Cinco vezes favela (1962)3.

A diegese de Os herdeiros acompanha três gerações de uma família, de 1930 a 1964. Jorge Ramos (Sérgio Cardoso) é um jornalista que se casa com a filha (Isabel Ribeiro) de um rico fazendeiro (Mário Lago), em 1930. Já no período democrático, ascende socialmente, tornando-se dono de uma grande rede de comunicação. Embora ainda casado, é completamente apaixonado por sua amante (Odete Lara). Em 1964, ano do Golpe civil-militar, é assassinado por Joaquim (André Gouveia), um de seus filhos, ideologicamente vinculado à esquerda.

Como adiantei acima, trata-se de um filme histórico moderno. As pistas para as subversões do gênero já podem ser encontradas no subtítulo da obra: "Uma estória de nossa história, de Carmem Miranda a Brasília, de Getúlio Vargas à televisão, uma alegoria sobre a História do Brasil e a luta pelo poder desde a Revolução de 30". Trata-se de um subtítulo excepcional, que tanto pela extensão quanto pelo nível de detalhamento caberia melhor em um livro acadêmico. Um relato do diretor sobre a trajetória do filme permite entender a necessidade de tal aposto:

\footnotetext{
O título no qual me havia fixado desde o início era "O brado retumbante", que é uma expressão de um verso do Hino Nacional Brasileiro. Eu filmei em 1968, entre a filmagem e a montagem veio o golpe militar de dezembro, o Ato 5. Terminei o filme sob a ditadura. Nesse momento recebi uma comunicação oficiosa da censura de que esse título não seria aprovado de jeito nenhum (OROZ, 1984: 64).
}

3. Não coincidentemente, Cacá Diegues foi o coordenador do projeto que permitiu a realização de Cinco vezes favela - agora por nós mesmos (2010). 
Assim, a um título altamente comunicativo - afinal, o brado retumbante ano 2 número 3 do hino nacional é imediatamente reconhecido e carrega referências ao povo heroico que o emitiu - vem em substituição Os herdeiros, mais hermético. Daí a necessidade de um subtítulo, que marca de forma enfática de que trata o filme. De fato, as suas definições dão pistas sobre a natureza narrativa da obra, orientando a escolha de algumas cenas e sequências a serem analisadas a seguir.

Uma estória de nossa história aponta para o convívio entre personagens fictícios e históricos. Diferente de um filme clássico, em que os personagens devem ser "reais" para garantir a eficiência da fórmula tal como aconteceu, aqui a obra recorre também a personagens fictícios (que poderiam ser reais). Importante salientar que tanto os personagens históricos quanto os ficcionais se apresentam como ideias (personas). Jorge Ramos, centro da narrativa, não é um jornalista, é a própria imprensa. Sua esposa e sua amante não têm identidade, têm rótulos: "a mulher santa" e "a mulher puta". Seu sogro não é um dono de fazenda de café, é o coronelismo. Cada um de seus filhos, por sua vez, substituiria a esquerda e a direita.

A mesma lógica poderia ser aplicada aos personagens históricos. A continuação do subtítulo diz: “de Carmem Miranda a Brasília, de Getúlio Vargas à televisão”. Carmem Miranda e Getúlio Vargas estariam ali, portanto, no lugar do passado - em oposição a Brasília e à TV, representando o presente (da diegese). Porém, diferente de uma representação naturalista que intentaria "ressuscitar" tais personagens, o filme parece evocar as sua sombras.

No caso de Carmem Miranda, haveria muitos recursos para se aproximar da personagem. Entre eles, a utilização de celuloides, numa alusão à "verdade" dos registros fílmicos, ou uma atriz, num jogo de faz-de-conta que possibilitaria levar os espectadores a crer que estivessem diante de Carmem Miranda. A opção escolhida, contudo, escapa a essa alternativa, acrescentando mais camadas de sentido à presença da cantora/atriz na trama.

Afinal, no lugar de Carmem Miranda aparece um transformista que mimetiza a tal figura, ensaiando uma cena - aqui, em duplo sentido, já que o enquadramento da câmera corresponde à boca de um palco de teatro. Embora num primeiro 
momento se pudesse pensar que uma atriz ou um transformista não se diferiam tanto entre si, acho importante salientar que a figura do travesti está carregada de memória. Sei, ao assistir ao filme, que Carmem Miranda é um dos ícones mundiais da cultura gay, uma das mulheres mais imitadas por homens em palcos. Assim, o filme não tenta me iludir com uma atriz que poderia ser Carmem, se eu aceitasse o jogo. Pelo contrário, sou lembrado de que ali não está Carmem Miranda, mas alguém que mantém sua memória, que é sua memória.

Vale ressaltar que tal memória também está associada a uma leitura de Brasil, já que seus requebros e figurinos kitsch remetem a um nacionalismo cunhado durante o Estado Novo. O processo está baseado na modernização de aspectos da cultura popular, como o samba e o folclore (como atesta a figura da baiana que Carmem representava), tudo regado a uma tropicalidade estilizada, marcante nas frutas que enfeitavam seu turbante (AMANCIO, 2001; FREIRE-MEDEIROS, 2005). Além disso, o cenário por trás da apresentação é uma paisagem naïf do Pão de Açúcar, o que remete ao teatro de revista e às chanchadas, por certo, mas também ao papel que o Rio de Janeiro desempenhou como vitrine do Brasil e caixa de ressonância da nação. Afinal, a capitalidade carioca, foi um dos elementos que possibilitaram diversas reelaborações da nacionalidade (PINTO, 2013).

Getúlio Vargas, por sua vez, também aparece menos como personagem e mais como persona, representando o trabalhismo. Para essa leitura, é significativa a sequência em que Jorge Ramos dialoga com Vargas na sala de reunião ministerial do Palácio do Catete, momentos antes de o presidente se suicidar. Novamente há um enquadramento em plano aberto - aqui exibindo os atores dispostos estrategicamente no espaço: enquanto Getúlio permanece parado em uma das cabeceiras da mesa, Jorge Ramos se desloca constantemente pelo espaço, demonstra alteração de humor. Ao fundo, está visível a pintura $A$ pátria, de Pedro Bruno, que representa uma família costurando a bandeira nacional - o que, alegoricamente, corresponderia à tessitura da pátria.

O ator que representa Vargas - Armando Nascimento, reconhecido por suas caricaturas do presidente no teatro de revista (OROZ, 1984) - permanece parado, ereto, olhando fixamente para frente, enquanto declama trechos da carta-testamento de Getúlio, entremeados a outros textos. Não existe pausa 
ano 2 número 3

Dossiê

entre suas falas e as de Jorge Ramos, que grita comentários irados sobre o texto do presidente. Não apenas a respeito do texto, mas também sobreposto a ele (como um som over). A sequência é a assunção de que Jorge Ramos debate, não com Getúlio, mas com as projeções (sombras) do que este representava. Ao fim, o presidente conclui: "Saio da Vida para entrar na história", o que Jorge Ramos acusa ser mentira, pois quem faz a história são os vivos.

Os outros elementos constantes do subtítulo, Brasília e a TV, referem-se ao presente, como já indiquei. A nova capital, apesar de inaugurada nove anos antes de o filme ser realizado, fazia parte de sua contemporaneidade diegética. Caso se aceite que uma cidade pode ser personagem de um filme, Brasília está aquém de suas possibilidades. Afinal, permanece apenas alusiva, quase como um cenário tradicional de ópera, um pano caído ao fundo do palco. A TV tem apenas uma referência rápida, quando Jorge Ramos alude ao poder que teria quem a dominasse - o que poderia ser apenas uma prospecção em 1964, mas já era fato consumado em 1968. Como pode ser percebido, tanto a TV quanto Brasília não têm o peso que Getúlio Vargas e Carmem Miranda ocupam. Ambas são capazes de representar a força da modernização, a abertura do Brasil para o mundo e para o futuro - mas ficam "apagadas" diante das referências ao passado. De fato, o subtítulo avisa: Os herdeiros é uma alegoria da História do Brasil e, numa alegoria, o papel do presente é mesmo ficar atrás, é ser o não-dito (RAMOS, 2002).

A sensação de que a trama se desenrola em palcos (os "palcos da história") é dada pelo plano geral muito presente, pela existência de palcos diversos na diegese (Rádio Nacional, teatros, palanques) e pela trilha sonora. Nessa, posso ouvir desde o cancioneiro popular em apresentações de estrelas da MPB (Dalva de Oliveira, Caetano Veloso) até óperas de Villa-Lobos no som extradiegético. As atuações brechtianas dos atores também depõem sobre essas opções. Não se trata de espetáculo histórico, onde o espectador voyeur se delicia em acompanhar a trajetória de personagens do passado. É encenação de palco e a quarta parede é rompida: as personas discursam, falando diretamente para a câmera/público mas também se debatem e rastejam. É como se permanecesse o desejo de dizer, de falar ao público - o que era típico do Cinema Novo desde o início -, mas tal ação não pudesse se completar no presente. 
Quanto mais a diegese se aproxima de 1964, mais os personagens parecem se debater na angústia do presente onde não podem mudar o passado e, mais importante, já não acreditam poder mudar o futuro. Estão inseridos em uma lacuna (ARENDT, 1968), espremidos pelo passado e pelo futuro simultaneamente. Jorge Ramos esbraveja contra o discurso de Getúlio Vargas, afirmando sua superioridade por ser capaz de fazer a história acontecer, com suas mãos de homem vivo. No entanto, suas relações com a história são agônicas, já que ela lhe persegue na figura de fantasmas (como o próprio Vargas).

Assim, a subversão do filme - frente à exortação da ditadura para que se fizessem filmes históricos - reside justamente no fato de "prender" o passado ao presente, trazendo os personagens históricos, em forma de sombras, para conviver com os vivos, que os julgam e acusam. Algumas reflexões de Cacá Diegues sobre o seu processo de criação podem auxiliar as forças que estavam em jogo nesse mecanismo de representação.

Em 1970, o diretor lembrava as reações que tivera diante da morte de Getúlio, quando adolescente: "Acho que foi nesse dia que conheci o sentido às vezes trágico da história" (DIEGUES, 1999: 8). Como visto, esse "sentido trágico" estaria muito presente em Os herdeiros, um filme feito "com esses sentimentos e lembranças (...)" (DIEGUES, 1999: 8). Por outro lado, acredito ser interessante também apontar outro depoimento de Cacá Diegues referente ao mesmo acontecimento, mas o abordando em termos distintos: “(...) foi o primeiro momento da minha vida em que percebi que a política podia ter uma dimensão trágica, a-histórica" (OROZ, 1984: 52). Trata-se, portanto, de uma indecisão entre considerar o passado como algo distante e localizado no tempo (como a história), ou perene e em constante pulsação (como a memória) - embora sempre, em qualquer dos casos, ele permaneça imutável, porque trágico.

Da mesma forma, Cacá Diegues oscila entre o histórico e o a-histórico em seu filme. Ali, a História - escrita propositadamente com maiúscula, em referência à grandiosidade que a ditadura lhe dava - é evocada, aparentemente como desejavam os ditadores. Porém, é violentamente retirada de seu pedestal e arrastada pelos cenários, até se tornar maleável e caber no espaço exíguo do presente - como a memória, que também é feita de passado, mas ainda latejante 
no presente. Contudo, não diria que o filme deixe de ser histórico por conta disso.

Afinal, os liames entre memória e história são mais estreitos do que aparentam. Nesse sentido, valeria lembrar a profissão de fé que Cacá Diegues fez em 1970, por ocasião da estreia de Os herdeiros:

\begin{abstract}
Daqui pra frente tudo vai ser diferente, mas é preciso enterrar o passado, esse morto fedorento (...). Que me desculpem os sociólogos, os historiadores, os cientistas, mas eu não tive a intenção de provar nada. [...] A profissão de vocês é muito séria, e dela depende a humanidade. A minha é um ofício doloroso de revelar fantasmas (...). [...] O tempo é a minha matéria, o tempo presente, os homens presentes, a vida presente. (DIEGUES, 1999: 9)
\end{abstract}

\title{
História, memória, história, memória ad infinitum
}

Reinhart Koselleck (2006) defende que, a partir da modernidade, o horizonte de expectativa (futuro) passou a ter muito mais importância que o campo de experiência (história, memória). Tal processo se deveu ao fato de que o futuro passou a ser imaginado, se tornando espaço de elaborações, de vivências sociais hipotéticas. Gilberto Velho (1994), por sua vez, afirma que os projetos de futuro estão vinculados com a formação de identidades, só erigidas devido à maleabilidade da memória. Haveria uma linha reta imaginária ligando passados, presente e futuros. Escolhe-se um entre os muitos pontos maleáveis do passado que, unido ao ponto-presente (imutável) determine a continuação da linha até um dos pontos do futuro (pluralizado pela imaginação).

Os filmes históricos mobilizam essa dinâmica, sendo uma das formas socialmente concebidas de se imaginar o futuro. Embora pretendam se relacionar com o passado a partir da história (a priori uma leitura precisa e objetiva do passado), muitas vezes o que se vê são interpretações pautadas pela memória. Com graus diversos de consciência, aqueles que realizam esse tipo de produção estão igualmente interessados nos processos de construção da identidade, o que significa dizer que também pretendem formar uma linha ligando os pontos passado-presente-futuro. 
Logo, a análise da construção de sentidos nos filmes históricos é um bom caminho para se compreender os mecanismos de construção de identidade, bem como a forma intrincada como se dão as relações entre memória e história. De fato, as tentativas de separar os dois campos sempre soam impotentes. O caso da representação de Getúlio Vargas em Os herdeiros é bem elucidativo: história ou memória? Quanto mais reflito, menos estou convencido de que seja possível decidir. Para tentar facilitar minha tarefa, recorro a alguns estudiosos que se lançaram ao trabalho hercúleo de tentar separar a memória da história.

Jacques Le Goff (1996), no verbete História da enciclopédia Einaudi, classifica a memória como mítica, deformada, anacrônica e parte do jogo de poder (pode ser manipulada). A história, por outro lado, tem um compromisso com a verdade e possui a tarefa de corrigir a perspectiva falsa apresentada pela memória coletiva. Descontado o tom pejorativo, a definição de memória chega próximo de um nível satisfatório. Por outro lado, como aceitar uma tentativa de vincular história e verdade sem classificá-la, no mínimo, como inocente? A história também faz parte do jogo de poder e pode ser tão maleável quanto a memória.

Para David Lowenthal (1988), memória e história são duas formas de tentar atingir o "país estrangeiro" que é o passado: a primeira corresponde ao passado lembrado e a segunda, ao passado registrado. Como se a memória, ao ser registrada, deixasse de ser memória. E como se a história não tivesse, também ela, uma memória. Pierre Nora (1984) também não se furta à tentativa de estabelecer as especificidades de cada área: entre outros pontos, afirma que a memória é vida, sempre carregada por grupos em permanente evolução, enquanto a história é reconstrução sempre problemática e incompleta do que não existe mais. É preciso lembrar que o autor se refere à "memória verdadeira”, ou seja, à memória das sociedades primitivas, sem escrita. Isso se mostra como empecilho para se usar sua definição como fonte de discussão sobre a memória nas sociedades complexas.

Henry Rousso, ao tentar estabelecer os limites da "história erudita" em relação à memória, afirma que o principal problema é a discrepância entre o que ela 
ano 2 número 3

Dossiê

"possa dizer de um acontecimento do passado e as percepções que prevaleçam no mesmo momento no seio de uma sociedade, (...) que certamente têm peso infinitamente maior" (1998: 97). Assim, o autor volta à espécie de disputa a que Jacques Le Goff alude.

Então seria impossível separar e "apaziguar" memória e história? O mesmo Le Goff que tenta uma separação algo esquemática no exemplo dado acima, retorna com uma segunda tentativa bem mais sofisticada e satisfatória: "A memória [é] onde cresce a história, que por sua vez a alimenta (...)" (LE GOFF, 1996: 47). Tal definição, que leva em conta a relação simbiótica das duas áreas ao evocar a imagem de uma árvore e sua ligação com o solo do qual nasce e que vem a alimentar com suas folhas apodrecidas, dá conta da complexidade da questão. Duas que são uma, sem deixarem de ser duas. Quase um mistério místico, uma "santíssima dualidade".

Os filmes históricos modernos - ao menos os abordados aqui - entendem e respeitam tal relação. Por um lado, permitem a temporalização do assunto tratado, ação típica da história. Por outro, presentificam o passado, papel cumprido pela memória. Evidente que, no vasto rol de possibilidades da linguagem cinematográfica, os filmes históricos - mesmo quando partilham a característica de serem modernos - podem efetuar essa operação de formas distintas. É o que pretendo demonstrar agora, a partir da abordagem de Coronel Delmiro Gouveia.

\section{Toda história tem seus fantasmas}

Lembro o já comentado discurso do ministro da Educação e Cultura, Jarbas Passarinho, exortando os cineastas a realizarem filmes que se debruçassem sobre aspectos vários da história do Brasil. As instituições e personagens referidos eram históricos, e deveriam aparecer em filmes históricos - mas o objetivo da política era preservar a memória. Como apresentei inicialmente, os empreendimentos da ditadura civil-militar no campo cinematográfico estavam inseridos num horizonte mais amplo, em que se encontrava uma política cultural centrada na preservação de determinada memória, apresentada como história. 
Todavia, a memória é simultaneamente fiel e móvel, como lembra Jacques Le Goff (1986), e está bem intricada como o esquecimento. Preservá-la não significa perpetuar o estabelecido, o terminado, mas administrar a maleabilidade de um processo sempre em andamento. Devido a essas características, preservar a memória implica sempre em esculpi-la, entregando-se ao trabalho de subtrair ao seu corpo aquilo que termina por cair nas águas do Lete, simultaneamente rio e deusa da memória, segundo a mitologia grega (WEINRICH, 2001). Não obstante o caráter por vezes involuntário do esquecimento, não é rara a presença da intencionalidade.

A partir do que foi apresentado, posso inferir que a cada concepção de memória corresponde uma maneira de se perceber a história. Logo, a memória que se pretendia preservar/ construir no Brasil ditatorial mantinha relações com uma história ufanista, povoada de heróis envolvidos em conflitos sempre associados a uma ameaça externa. Os conflitos internos - e, por conseguinte a sua memória - como a escravidão, a discriminação racial, o genocídio dos povos autóctones e o autoritarismo deveriam ser apagados ou atenuados. Como visto, o esforço de edificação dessa memória pretendia apresentar uma imagem de país longe da realidade apontada por uma historiografia crítica.

A utilização do termo imagem na sentença acima tem uma razão que ultrapassa os limites do sentido figurado. No empenho de edificação da memória, as imagens têm importância central, desde a antiguidade, com o surgimento da mnemotécnica, a arte da memória (ALMEIDA, 2010). Tal arte consistia em construir imaginariamente um edifício (um palácio ou um teatro, por exemplo) e nele dispor, em lugares de destaque, imagens que, por associação, remetessem ao que deveria ser lembrado. Na era moderna, é interessante destacar as relações entre a memória visual e os monumentos públicos, além das pinturas históricas (CARVALHO, 1990) e o cinema.

Um caso clássico é a cinematografia norte-americana, que através da escolha e tratamento de temas diversos (conquista do Oeste através dos westerns, Segunda Guerra Mundial, Guerra do Vietnã, entre outros) conseguiu impor uma determinada memória que não se coaduna com perspectivas mais críticas sobre sua história (HOBSBAWM e RANGER, 1997). Apesar de não se constituir num 
ano 2 número 3

Dossiê

privilégio dos filmes históricos, essa capacidade de convencimento do cinema esteve sempre por trás das produções históricas, conforme indicam alguns estudos clássicos, como o de Leif Furhammar e Folke Isaksson (1976), e outros mais recentes, como o de Mark C Carnes (1997).

Geraldo Sarno, roteirista e diretor de Coronel Delmiro Gouveia, precisou se deparar com questionamentos semelhantes aos expostos acima quando decidiu realizar o filme. Afinal, estava se aproximando de um tema caro à ditadura, num momento em que a Política Nacional de Cultura (PNC) estava estruturada, dispondo de formas de coerção mais sofisticadas. Além de ter sido produzido pela Embrafilme, o filme dialogava com o discurso oficial. Aos leitores atentos, e com boa memória, acredito não tenha escapado o fato de que Delmiro Gouveia - pioneiro da industrialização brasileira, assassinado por concorrentes ingleses - é um dos "heróis" que aparecem no discurso bastante ufanista de Jarbas Passarinho. Daí, uma questão inevitável é: apesar de realizado em torno de sete anos após o discurso, o filme poderia ser encarado como uma consequência dele? Seria, enfim, um agente de memória da ditadura?

Os antecedentes de Geraldo Sarno apontam para uma resposta negativa. Integrante do Cinema Novo, o diretor e roteirista havia sido o responsável por um clássico do documentário brasileiro, Viramundo (1965). Com uma perspectiva crítica e incisiva sobre a miséria nordestina, o filme, como muitas outras obras cinemanovistas, causara incômodo à visão conservadora da ditadura civil-militar. Além disso, Coronel Delmiro Gouveia, mesmo sendo o primeiro filme de ficção de Sarno, não destoa de suas outras criações, que ainda mantinham unidade temática e estética.

De fato, a forma escolhida pelo diretor, em parceria com Orlando Senna, para contar a história de Delmiro Gouveia confirma tal intuição. Em vez de recorrer a uma narrativa neutra, com ponto de vista onisciente, o que daria a impressão de que a história fosse narrada a partir de um não-lugar, o filme é contado por quatro personagens que estiveram envolvidos com Delmiro Gouveia (Rubens de Falco). Assim, é reforçada a ideia de que a história é narrada por alguém - no caso, por quatro pessoas com interesses muito diferentes em relação à figura central. 
No início, a narradora é Eulina (Sura Berditchevsky), a segunda mulher de Delmiro, que o trata como um herói romântico, admirado em todo o Recife; em seguida, o coronel Ulisses (Jofre Soares), que acolheu o casal durante um tempo por motivos de perseguição política e o vê como um homem de valentia, como um par; o terceiro narrador é Iona (Nildo Parente), o sócio de Delmiro na fábrica, encarregado das contas, que o aponta como um sonhador, idealista; finalmente, Zé Pó (José Dumont), retirante transformado em operário, que já começa seu relato a partir da morte de Delmiro, ou seja, após a compra da fábrica pelos ingleses.

Essa opção aproxima o filme da metodologia da história oral (FERREIRA e AMADO, 1998), em que o conceito de memória é fundamental. A partir da difusão dessa metodologia, a memória coletiva passou a fazer parte dos estudos históricos em duas dimensões mais gerais: na primeira, a memória é invocada para subverter as afirmações da história escrita; na segunda, é a história acadêmica que, através de suas divulgações mediatizadas (como os filmes), é considerada capaz de influenciar as memórias sobre o passado (THOMSON et al., 1998).

É interessante que os dois termos mais genéricos utilizados para marcar a relação de um filme com a realidade sejam documentário e ficção. No caso de um filme histórico, isso gera um problema: caso não seja um documentário sobre um tema historiográfico, o filme será classificado como ficção. No entanto, por tratar de acontecimentos reais, esse filme não poderia ser considerado ficcional (como uma história imaginada). Na obra em questão, há uma forma documental - extremamente ligada à memória - ficcionalizada. Personagens reais, vividos por atores, fazem relatos fictícios - no sentido de que essas personagens nunca deram, de fato, os depoimentos que se ouve em over -, mas que poderiam ter acontecido.

Assim, Geraldo Sarno, ao realizar uma ficcionalização de uma história real dá à narrativa um tratamento semelhante ao de um documentário - que, por sinal, é o formato mais frequente em sua carreia. Embora não haja uma única forma que possa ser atribuída aos documentários, existem linhas genéricas (RAMOS, 2012). Em Coronel Delmiro Gouveia, a estratégia consiste em aproximar-se do assunto/personagem abordado através de entrevistas com um universo variado de pessoas. Nesse sentido, são interessantes as observações de José Carlos Avellar: 
O relato de Eulina começa em 1900. Terminados os letreiros temos Delmiro, Iona e Anunciada, a primeira mulher de Delmiro, diante do relógio fazendo brindes ao Brasil para comemorar o novo século. O relato de Zé Pó vem até 1930, até a destruição da Fábrica da Pedra. Pois bem, o que se passou na sociedade brasileira está mais ou menos documentado no estilo dos quatro depoimentos. No estilo de falar, na visão que cada personagem tem das situações que narra, e não propriamente nos fatos narrados. Ou seja, a estrutura romântica da narração de Eulina corresponde muito à visão que a sociedade brasileira tinha de si mesma no começo do século, assim como o coronelismo e o cangaço do episódio de Ulisses, a capitalização do país no episódio de Iona e, finalmente, o aparecimento de uma classe operária no episódio de Zé Pó, correspondem às etapas que se seguiram até a revolução de 30 (AVELLAR, 1979: 24).

Nesse jogo, a informação que obtenho é dupla: além do que é objetivamente dito, também fico conhecendo aqueles que narram, e por sua vez, as coletividades de que fazem parte. Coletividades (no plural) porque, como defende Paul Ricoeur (2000), toda memória é individual e coletiva simultaneamente. No filme, é possível perceber essa afirmação com clareza: cada personagem-narrador é próximo de Delmiro Gouveia, mas representa também amplas coletividades.

Assim, além de se inteirar a respeito de múltiplos aspectos da personalidade e da biografia do coronel, é possível conhecer também algo sobre sua mulher (e sobre a mulher na sociedade brasileira do início do século XX), sobre seu empregado (e sobre os operários no final da década de 1920), sobre seu par, outro coronel (e sobre o coronelismo) e sobre seu sócio, um homem de negócios pragmático (e sobre capitalismo no Brasil do início do século XX). Lentes que se sobrepõem e testemunham sobre o que foi visto e sobre quem viu e conta. Lentes para o objeto central - Delmiro Gouveia - e para os objetos periféricos nem por isso menos importantes - todos componentes da sociedade brasileira. Não uma biografia, mas um entrecruzamento de biografias.

Essa característica da narrativa também aparece no tratamento dado ao tempo. O filme apresenta algumas datas em legendas e em referências nas falas das personagens. Também existem elipses e mudanças nos cenários ou figurinos. 
Porém, esses recursos são usados de forma convencional, sem chamar muita atenção. No que se refere à montagem, também não há grandes arroubos de criatividade: a história é narrada de forma linear, com princípio, meio e fim. No entanto, a forma como as qualidades do tempo são expostas possibilita reflexões inovadoras. Afinal, acredito que cada narrador (cada parte do filme) corresponda a um tempo diferente. Não apenas a uma cronologia diferente - como José Carlos indica - mas a qualidades de tempo diferentes.

Desse modo, o roteiro de Coronel Delmiro Gouveia confere ao tempo quatro contadores de história que, além de observadores, funcionam também como representantes de tempos distintos. Cada qual se localiza numa temporalidade diferente e representa uma mudança na percepção do tempo: romântico, autoritário, corporativo (time is money) e mecanizado. Quatro pontos de vista representados por quatro imagens/ personagens distribuídos por um constructo denominado filme.

Os artistas da memória da antiguidade, aqueles que dominavam a mnemotécnica, construíam edifícios de memória: um espaço - que poderia ser um palácio ou um teatro - e dispunham em seus aposentos imagens que correspondiam ao que desejavam lembrar. Como artistas da memória, Geraldo Sarno e Orlando Senna dispuseram quatro personas em pontos sucessivos do filme (seu espaço de memória), ligando a cada uma delas uma concepção de tempo, de sociedade e de coronel Delmiro Gouveia: homem da cidade, impulsivo, apaixonado; homem do sertão, coronel, destemido; homem de negócios, empreendedor, idealista; patrão, ríspido e violento, compreensivo e bom; explorador e salvador. Tantas imagens e seus avessos. Todos os plurais, todos os Delmiros Gouveias e ainda mais.

Trata-se, enfim, de uma aproximação semelhante à que é perpetrada em $O s$ herdeiros, ainda que mais centrada e pragmática. Percebemos que, mesmo lidando com personagens históricos - incluído o protagonista - o filme não pretende "ressuscitá-los". Menos que indivíduos, eles representam coletividades. Falam por eles e por outros. Em relação a Delmiro Gouveia, essa impressão é ainda mais 
reforçada. Não é tanto à figura do coronel que o filme dá acesso, mais aos seus espectros, a suas imagens refletidas nos espelhos de seus próximos. Continua a ser, portanto, um relato de fantasmas. Por certo, não era esse o resultado que Jarbas Passarinho buscava quando incluiu Delmiro Gouveia em seu discurso.

\section{Memória: combates na sombra}

Comparando o filme de Geraldo Sarno com o de Cacá Diegues, percebo que há, no segundo, muito mais matéria de memória que no primeiro. Memória individual, quero dizer. Os fluxos visuais de Os herdeiros me remetem sempre a fluxos de memória. Nesse sentido, Silvia Oroz compreende a sua montagem da seguinte forma:

O filme tem a estrutura de quadros sequenciais, cuja ordem pode ser modificada sem que se perca a compreensão dos fatos. Cada quadro, por sua vez, começa com uma concepção realista e evolui até uma síntese abstrata, gerando uma síntese de cada período histórico (OROZ, 1984: 54).

O filme "lembra" aos pedaços, assim como lembram os indivíduos: sem enredo, sem início-meio-fim. Os inícios realistas parecem uma tentativa de ancorar a memória na razão. Como se a cada início de quadro, uma nova lembrança estivesse brotando e se fizesse uma tentativa de entendê-la. Mas, ao fim, o caráter diáfano e maleável da memória prevalece. Assim, Os herdeiros é um filme que expõe memórias, mas não é bom construtor de memória. O próprio diretor dá a pista: "É preciso ver o filme como os franceses falam: le roman fleuve ${ }^{4}$, porque é um filme fleuve, uma coisa que corre aos borbotões e permite diversas leituras, não é só uma narração política da história do Brasil" (OROZ, 1984: 53).

A fluidez que permite diversas leituras não é uma boa estratégia de criação de memória. Como disse "sabiamente" o presidente Médici, o filme ideal para criar memória devia ter "temas que emocionam e educam comovem e informam as

4. A tradução mais adequada para roman-fleuve seria "saga", mas Cacá Diegues parece se referir ao sentido literal: algo como um "romance-rio". 
nossas plateias" (JORNAL DO BRASIL, 1972) $)^{5}$. Emocionar e educar, comover e informar não são, definitivamente, as propostas de Os herdeiros. E posso perceber isso na memória que tenho do filme. Lembro mais de sua estrutura e de aspectos gerais que de um enredo.

Já Coronel Delmiro Gouveia tem uma estrutura mais organizada e lida com a narrativa com a mesma destreza de um artista da memória. É, sim, um filme que dá a conhecer. Não quero dizer, com isso, que siga as instruções de Médici, que seja um filme nos moldes da ditadura. A memória desejada pela ditadura se concentraria na figura do coronel como homem empreendedor, industrial avant garde. O filme vai além, se desviando do risco de fazer culto de personalidade. A memória que constrói é coletiva, social. Mesmo realizado depois da organização da Política Nacional de Cultura (PCN) e sendo uma produção "oficial”, o filme não corresponde à interpretação da história defendida pela ditadura. Aliás, o fato mesmo de incluir, entre as memórias apresentadas, a de um operário, já atingia um ponto frágil da ditadura: a mobilização popular (MAYNARD, 2006).

Enfim, em ambos os filmes analisados aqui, a memória foi mobilizada como elemento desestabilizador da cultura história que a ditadura pretendia erguer, tendo o filme histórico como um de seus meios. No primeiro, Os herdeiros, Cacá Diegues constrói uma reação mais visceral, de acordo com o momento vivenciado - à violência generalizada, ao clima persecutório, respondeu com seus fantasmas, memórias-vivas a assombrar a História. Geraldo Sarno e Orlando Senna, por sua vez, encontravam uma situação diferente, em que o discurso mais organizado e a infraestrutura burocrática da ditadura exigiam uma resposta menos passional, pautada em uma metodologia que procurasse ampliar, pela memória, os limites de um personagem que tinha tudo para ser "apenas" um herói nacional.

5. Trecho de um telegrama do então presidente brasileiro elogiando o resultado do filme Independência ou morte (Carlos Coimbra, 1972), um os filmes históricos clássicos que, como indiquei, foi uma dos grandes sucessos de bilheteria da década de 1970, sendo encampado pela ditadura. 


\section{Referências}

ALMEIDA, M. J. de. C. - arte da memória. Campinas, SP: Autores Associados, 2010.

ALTUNA, J. L.. "Acerca de la condición política de lo artístico en la sociedad del conocimiento". Concinnita. Revista do Instituto de artes da UERJ, ano 8, vol 1, n. 10, julho de 2007.

AMANCIO, T. Artes e manhas da Embrafilme - cinema estatal brasileiro em sua época de ouro - 1977-81. Niterói: EDUFF, 2000.

. O Brasil dos gringos: imagens no cinema. Niterói: Intertexto, 2001.

ARENDT, H. "Between past and future: eight exercises". In: . Political thought. Enlarged edition. New York: Penguin Books, 1968.

AVELLAR, J. C. "O velho e o novo". In: SENNA, Orlando e SARNO, Geraldo. Coronel Delmiro Gouveia: roteiro do filme. Rio de Janeiro: Codecri, 1979.

BERSTEIN, S. "Enjeux. L'historien et la culture politique". Vingtièmesiècle. Revue d'histoire, $n^{\circ} 35,1992$.

CARNES, M. C. O passado imperfeito - a história no cinema. Rio de Janeiro/ São Paulo: Ed. Record, 1997.

CARVALHO, J. M.. A formação das almas: o imaginário da república no Brasil. São Paulo: Companhia das Letras, 1990.

DIEGUES, C. Cinema brasileiro: ideias e imagens. Porto Alegre: Editora Universidade/ UFRGS/ MEC/SESu/PROED, 1999.

FERREIRA, M. M. \& AMADO, J. Usos e abusos da História Oral. Rio de Janeiro: Ed. FGV, 1998.

FREIRE-MEDEIROS, B. O Rio de Janeiro que Hollywood inventou. Rio de Janeiro: Jorge Zahar, 2005.

FURHAMMAR, L. e ISAKSSON, F. Cinema e política. Rio de Janeiro: Paz e Terra, 1976.

GOMES, A. C.. "Cultura política e cultura histórica no Estado Novo". In: ABREU, M. et al. Cultura política e leituras do passado. Rio de Janeiro: Civilização Brasileira, Faperj, 2007. 
HOBSBAWM, E. \& RANGER, T. A invenção das tradições. Rio de Janeiro: Paz e Terra, 1997.

KOSELLECK, R. Futuro Passado: contribuição à semântica dos tempos históricos. Rio de Janeiro: Contraponto, 2006.

LE GOFF, J. "História”. Memória/história. Lisboa: Imprensa Nacional/ Casa da Moeda, 1986 (Enciclopédia Einaudi, v. 1).

MAYNARD, D. C. S. "A fabricação da memória no filme Coronel Delmiro Gouveia". O olho da História, ano 12, n 9, dezembro de 2006.

NORA, P. Les lieux de mémoire. Paris: Gallimard, 1984.

OROZ, S. Os filmes que não filmei. Rio de Janeiro: Rocco, 1984.

ORTIZ, R. Cultura brasileira e identidade nacional. São Paulo: Brasiliense, 1986.

PINTO, C. E. P. de. O futuro do pretérito: a representação da história em filmes cinemanovistas (1968-1980). 2005. Dissertação (Mestrado). Rio de Janeiro, PUC-Rio.

. Imaginar a cidade real: o Cinema Novo e a representação da modernidade urbana carioca (1955-1970). 2013. Tese (Doutorado). Niterói, UFF.

. "Tudo deve falar do Golpe? Os limites da ditadura civil-militar como chave interpretativa da representação urbana nos filmes do Cinema Novo". Revista Contemporânea. Ano 3, n³, 2013, verão.

RAMOS, A. F. Canibalismo dos fracos - cinema e história do Brasil. Bauru, SP: EDUSC, 2002.

RAMOS, F. (org.). História do cinema brasileiro. São Paulo: Art Editora, 1987.

. "A mise-em-scène do documentário: Eduardo Coutinho e João Moreira Salles".

Rebeca, edição 1, n1, janeiro-junho de 2012.

RAMOS, J. M. O. Cinema, estado e lutas culturais: anos 50, 60 e 70. Rio de Janeiro: Paz e Terra, 1983.

RICOEUR, P. La memoire, l'histoire, l'oubli. Paris: Seuil, 2000.

RIDENTI, M. Em Busca do Povo Brasileiro. Rio de Janeiro; São Paulo: Editora Record, 2000. 
ROSENSTONE, R. A história nos filmes, os filmes na história. São Paulo: Paz e Terra, 2010.

ROUSSO, H. "A memória não é mais o que era". In: FERREIRA, Marieta de Morais e AMADO, Janaína. Usos e abusos da História Oral. Rio de Janeiro: Ed. FGV, 1998.

SENNA, O. \& SARNO, G. Coronel Delmiro Gouveia: roteiro do filme. Rio de Janeiro: Codecri, 1979.

THOMSOM, A. et al. "Os debates sobre memória e história: alguns aspectos internacionais". In: FERREIRA, Marieta de Morais e AMADO, Janaína. Usos e abusos da História Oral. Rio de Janeiro: Ed. FGV, 1998.

VADICO, L. "O épico bíblico hollywoodiano - o espetáculo como estética da salvação". Rebeca, Ano 1, edição 2, nº 2, Julho-Dezembro 2012.

VELHO, G. Projeto e metamorphose: antropologia das sociedades complexas. Rio de Janeiro: Jorge Zahar, 1994.

WEINRICH, H. Lete: arte e crítica do esquecimento. Rio de Janeiro: Civilização Brasileira, 2001.

\section{Periódicos}

FILME CULTURA. Ano IV, nº 19, jan./ fev., 1971.

JORNAL DO BRASIL. Rio de Janeiro, Ano LXXXII, n. 139, 07/09/1972, Caderno B. 